\title{
Effect of Linseed Oil Supplementation on Production, Composition and n-6/n-3 Fatty Acid Ratio in Cow's Milk
}

\author{
Pitunart Noosen $^{1}$, Pipat Lounglawan ${ }^{2 *}$, Supreena Srisaikham ${ }^{3}$, and \\ Wisitiporn Suksombat ${ }^{2}$
}

\begin{abstract}
${ }^{1}$ Department of Animal Science, Faculty of Natural Resources, Prince of Songkhla University, Songkhla 90112, Thailand

${ }^{2}$ School of Animal Technology and Innovation, Institute of Agricultural Technology, Suranaree University of Technology, Nakhon Ratchasima 30000, Thailand

${ }^{3}$ Faculty of Agricultural Technology, Burapha University, Sakaeo Campus, Sakaeo 27160, Thailand

*Corresponding Author.E-mail: pipat@sut.ac.th

https://doi.org/10.12982/CMUJNS.2020.0002
\end{abstract}

Received: October 31, 2018

Revised: April 19, 2019

Accepted: May 1, 2019

\begin{abstract}
The effects of linseed oil supplementation on milk production, milk composition, and n-6/n-3 ratio of dairy cow's milk were studied. Twenty-four Holstein Friesian crossbred lactating dairy cows were assigned into a $2 x 2$ Factorial arrangement. All cows were fed approximately $6 \mathrm{~kg} / \mathrm{d}$ of $21 \% \mathrm{CP}$ concentrate. Treatments were: 1) concentrate plus $300 \mathrm{~g} / \mathrm{d}$ of palm oil (PO) together with ad libitum corn silage (CS); 2) concentrate plus $300 \mathrm{~g} / \mathrm{d}$ of linseed oil (LSO) together with ad libitum CS; 3) concentrate plus $300 \mathrm{~g} / \mathrm{d}$ of $P O$ together with ad libitum fresh grass (FG); and 4) concentrate plus $300 \mathrm{~g} / \mathrm{d}$ of LSO together with ad libitum FG. Supplementation with LSO had no effect on DMI, milk production and milk composition. Milk fat content was also not affected by LSO supplementation. However, the milk C18:3n3 percentage was increased while n-6/n-3 FA ratio was decreased by LSO supplementation. It was concluded that the milk FA composition can be altered by $300 \mathrm{~g} / \mathrm{d}$ LSO supplementation with increasing concentrations of potentially health beneficial FA and decreasing concentrations of SFA. Finally, LSO supplemented with ad libitum FG lowed n-6/n-3 FA ratio in dairy cow's milk.

Keywords: Linseed oil, Milk fatty acid, n-6/n-3 Fatty acid ratio, Dairy Cow's milk
\end{abstract}




\section{INTRODUCTION}

The nutritional contribution of milk and the potential health effects of its main components (fat, protein, antioxidants, vitamins, and minerals) have been reviewed extensively (Steijns, 2008). However, milk contains a high proportion of saturated fatty acids ( SFA) because of extensive biohydrogenation of dietary unsaturated fatty acids (UFA) in the rumen and de novo synthesis of short- and medium chain saturates in the mammary gland (Shingfield et al., 2008). SFA and trans fatty acids in milk fat are relative proportions of high and low density lipoprotein cholesterol resulting in coronary heart disease (CHD). Thus, the milk industry aims to improve the nutritional quality of milk fat by reducing SFA and increasing the content of n- 3 series FA, including alpha linolenic acid (ALA), which is recognized as minimizing the risk of cardiovascular disease and is equally essential for the functional development of the central nervous system (Ambroise, 2001). The fatty acid distribution in milk fat is dependent on dietary composition (Dewhurst et al., 2003). It is now well established that supplementation of cow's diet with UFA affects milk FA profiles (Harvatine et al., 2009). The main sources of unsaturated lipids are oilseed lipids, among which linseed, rapeseed, soybean, and sunflower seeds (Glasser et al., 2008). Linseed oil contains the essential alpha-linolenic acid (ALA) which is oil from linseed (Linumusitatissimum) produced predominantly in the Great Plains and Canada. LSO supplementation caused a quadratic increase in milk fat and protein contents and supplementing grazing dairy cow diets with LSO at up to $510 \mathrm{~g} / \mathrm{d}$ can improve the nutritional value of milk without compromising milk composition or cow performance (Flowers et al., 2008). Previous studies compared the effects of TMR containing mixtures of fish oil and different sources of UFA or concentrate: forage ratio and LSO. The results suggested that the nature of supplemental PUFA added to high-concentrate diets likely altered the profile and amount of hydrogenation intermediates available for secretion in milk (Loor et al., 2005). Thus, the objective of this study was to determine the effects of LSO supplementation on milk production, milk composition, and n-6/n-3 ratio of dairy cow's milk.

\section{MATERIALS AND METHODS}

\section{Experimental design and treatments}

Twenty four Holstein Friesian crossbred lactating dairy cows, averaging $106 \pm 43$ days in milk, $12.1 \pm 3.0 \mathrm{~kg}$ of milk and $387 \pm 41 \mathrm{~kg}$ body weight, were blocked by parity first and then stratified random balanced for milk yield, milking days and body weight into four groups of 6 cows each. They were then assigned into a $2 \times 2$ Factorial arrangement. All cows were fed approximately $6 \mathrm{~kg} / \mathrm{d}$ of $21 \%$ $\mathrm{CP}$ concentrate. The concentrate fed $[(\mathrm{g} / \mathrm{kg}) 100$ cassava chip, 250 cassava meal, 100 rice bran, 120 palm kernel meal, 100 soybean meal, 70 bush bean, 75 corn gluten feed, 80 cassava ethanol, 60 liquid molasses, 20 urea, 20 dicalcium 
phosphate, and 5 premix] was fed 3 times daily. The oil supplementation was offered twice daily on top of concentrate fed. Treatments were: 1) concentrate plus $300 \mathrm{~g} / \mathrm{d}$ of palm oil (PO) together with ad libitum corn silage (CS); 2) concentrate plus $300 \mathrm{~g} / \mathrm{d}$ of LSO together with ad libitum CS; 3) concentrate plus $300 \mathrm{~g} / \mathrm{d}$ of PO together with ad libitum fresh grass (FG) (Napier; (Pennisetum purpureum $x$ Pennisetum americanum) older not more than 50 days). and 4) concentrate plus $300 \mathrm{~g} / \mathrm{d}$ of LSO together with ad libitum FG. All cows also had free access to clean water and were individually housed in a free-stall unit and individually fed according to treatments. The experiment lasted for 40 days of measurement period.

\section{Analytical procedures}

Feed offered and left after eating of individual cow were collected on 2 consecutive days of each $5 \mathrm{~d}$ period and dried at $60^{\circ} \mathrm{C}$ for $48 \mathrm{~h}$. At the end of the experiment, feed samples were pooled to make representative samples for proximate and detergent analyses. Samples were ground through $1 \mathrm{~mm}$ screen and analyzed for dry matter (DM, hot air oven at $60^{\circ} \mathrm{C}$ for $48 \mathrm{~h}$ ), crude protein (CP, Kjeldahl analysis) (AOAC, 1990), ether extract (EE, petroleum ether in a Soxtec System). Fiber fraction, neutral detergent fiber (NDF) and acid detergent fiber (ADF) were determined using the method described by Van Soest et al. (1991), adapted for Fiber Analyzer. Ash content was determined by ashing in a muffle furnace at $600^{\circ} \mathrm{C}$ for $3 \mathrm{~h}$. The chemical analysis was expressed on the basis of the final DM. Fatty acids composition of concentrates, fresh grass and corn silage were extracted using a modified of the method used by Folch et al. (1957) and Metcalfe et al. (1966) for analyzing by gas chromatography (GC) (7890A GC System, Agilent Technology, USA). Cows were weighed at the start and at the end of the experiment. Cows were milked twice daily at 05.00 and $15.00 \mathrm{~h}$ and milk yields were recorded for each cow. Milk samples from both the morning and evening milking were collected on 2 consecutive days of each 5-d period and stored at $4{ }^{\circ} \mathrm{C}$ with a preservative until analyzed for fat, protein, lactose and solid not fat content using Milkoscan FT $6000^{\circledR}$ (Foss Electric; Hillerod, Denmark). In addition, milk samples were extracted for fatty acid using a modified method used by Romeu-Nadal et al. (2004). From a well-mixed aliquot of milk, $3 \mathrm{ml}$ was placed in $50 \mathrm{ml}$ centrifuge tubes. Then added $27 \mathrm{ml}$ of a dichloromethanemethanol solution $(2: 1, \mathrm{v} / \mathrm{v})$ to each tube. The mixture was shaken mechanically for $15 \mathrm{~min}$ and centrifuged at $2,500 \times \mathrm{g}$ for $8 \mathrm{~min}$ at $4{ }^{\circ} \mathrm{C}$. Approximately $8 \mathrm{ml}$ of distilled water was pipette into each tube and, after shaking for a further $15 \mathrm{~min}$, the sample was, again centrifuged at $2,500 \times \mathrm{g}$ for $8 \mathrm{~min}$ at $4{ }^{\circ} \mathrm{C}$. As much of the upper aqueous fraction as possible was carefully removed with a pipette. The organic layer was washed with $8 \mathrm{ml}$ of a saturated solution of the sodium chloride, and finally mixed mechanically for $15 \mathrm{~min}$ and centrifuged for $8 \mathrm{~min}$ at 2,500 $\times g$ at $4{ }^{\circ} \mathrm{C}$. The upper aqueous fraction was carefully removed with a pipette. The organic fraction was carefully transferred to a separating funnel and filtered through 1PS paper (Whatman, Maidstone, UK) containing anhydrous sodium 
sulfate, and 3-5 $\mathrm{ml}$ of dichloromethane was passed through the filter. The fat solution was taken in pre- weighed conical flask. Finally, the extract was concentrated by removing dichloromethane in a rotatory evaporator and dried under a gentle stream of nitrogen. The weight difference of the conical flask before/after was assumed to be fat. The fat was stored at $-20{ }^{\circ} \mathrm{C}$ and redissolved in dichloromethane $(3 \%, \mathrm{w} / \mathrm{v})$ intermediately analyzing by gas chromatography (GC) (7890A GC System, Agilent Technology, USA). Fatty acid methyl esters (FAME) were prepared by the procedure described by Ostrowska et al. (2000). The procedure involved placing approximately $30 \mathrm{mg}$ of the extracted oil into a $15 \mathrm{ml}$ reaction tube fitted with a teflon-lined screw cap. One and a half $\mathrm{ml}$ of $0.5 \mathrm{M}$ sodium hydroxide in methanol was added. The tubes were flushed with nitrogen, capped, heated at $100{ }^{\circ} \mathrm{C}$ for 5 min with occasional shaking and then cooled to room temperature. One $\mathrm{ml}$ of $\mathrm{C} 17: 0$ internal standard $(2.00 \mathrm{mg} / \mathrm{mL}$ in hexane) and $2 \mathrm{ml}$ of boron trifluoride in methanol were added and heated at $100{ }^{\circ} \mathrm{C}$ for $5 \mathrm{~min}$ with occasional shaking and $10 \mathrm{ml}$ of deionized water were added. The solution was transferred to a $40 \mathrm{ml}$ centrifuged tube and $5 \mathrm{ml}$ of hexane were added for FAME extraction. The solution was centrifuged at $2,000 \mathrm{~g}$, at $10{ }^{\circ} \mathrm{C}$ for $20 \mathrm{~min}$ and then the hexane layer was dried over sodium sulfate and transferred into vial for analyzing by gas chromatography (GC) (7890A GC System, Agilent Technology, USA) equipped with a $100 \mathrm{~m}$ x 0.25 $\mathrm{mm} \times 0.2 \mu \mathrm{m}$ film fused silica capillary column (SP1233, SupelcoInc, Bellefonte, PA, USA). Injector and detector temperatures were $250{ }^{\circ} \mathrm{C}$. The column temperature was kept at $70{ }^{\circ} \mathrm{C}$ for $4 \mathrm{~min}$, then increased at $13{ }^{\circ} \mathrm{C} / \mathrm{min}$ to $175^{\circ} \mathrm{C}$ and held at $175^{\circ} \mathrm{C}$ for $27 \mathrm{~min}$, then increased at $4{ }^{\circ} \mathrm{C} / \mathrm{min}$ to $215^{\circ} \mathrm{C}$ and held at $215{ }^{\circ} \mathrm{C}$ for $17 \mathrm{~min}$, then increased at $4{ }^{\circ} \mathrm{C} / \mathrm{min}$ to $240{ }^{\circ} \mathrm{C}$ and held at $240{ }^{\circ} \mathrm{C}$ for $10 \mathrm{~min}$.

\section{Statistical analysis}

Measured data of intake, milk production, milk composition, and body weight change were analyzed by ANOVA for $2 \times 2$ Factorial in randomized complete block design using the Statistical Analysis System (SAS, 2001). Significant differences among treatment were assessed by Duncan's new multiple range test. A significant level of $P<0.05$ was used (Steel and Torries, 1980).

\section{RESULTS}

\section{Feed chemical and fatty acid composition}

The average EE content and energy values of the oil were higher than the concentrate diet, CS and FG, respectively (Table 1) C18:3n3 was the major fatty acid in the FG and LSO accounting for approximately $48.89 \%$ and $56.20 \%$ of total fatty acid, respectively. The second major fatty acid in the FG and LSO was 
C18:2n6 accounting for $19.03 \%$ and $17.04 \%$ of total fatty acid, respectively (Table 2). The LSO had similar proportion of n-3 FA to FG, but n-3 FA was almost absent from the PO.

Table 1. Chemical compositions of the experimental diets ( $\%$ of DM).

\begin{tabular}{lcccc}
\hline Item & $\begin{array}{c}\text { 21\% CP } \\
\text { Concentrate }\end{array}$ & $\begin{array}{c}\text { Palm oil/ } \\
\text { Linseed oil }\end{array}$ & Corn silage & Fresh grass \\
\hline Dry matter & 94.40 & - & 24.09 & 12.50 \\
Ash & 7.66 & - & 7.43 & 12.40 \\
Crude protein & 20.50 & - & 6.69 & 10.07 \\
Ether extract & 2.80 & 100 & 0.90 & 1.78 \\
Crude fiber & 12.67 & - & 29.28 & 36.04 \\
Neutral detergent fiber & 45.88 & - & 61.64 & 64.42 \\
Neutral detergent insoluble N & 1.51 & - & 0.46 & 0.32 \\
Acid detergent fiber & 22.79 & - & 26.51 & 34.43 \\
Acid detergent insoluble N & 0.81 & - & 0.54 & 0.35 \\
Acid detergent lignin & 7.17 & - & 3.41 & 2.62 \\
$\mathrm{TDN}_{1 \mathrm{x}}(\%)^{1}$ & 62.01 & 184.15 & 57.67 & 55.05 \\
$\mathrm{DE}_{1 \mathrm{x}}(\mathrm{Mcal} / \mathrm{kg})^{2}$ & 2.96 & 7.71 & 2.55 & 2.51 \\
$\mathrm{DE}_{\mathrm{p}}(\mathrm{Mcal} / \mathrm{kg})^{3}$ & 2.87 & 5.79 & 2.54 & 2.51 \\
$\mathrm{ME}_{\mathrm{p}}(\mathrm{Mcal} / \mathrm{kg})^{4}$ & 2.45 & 5.79 & 2.12 & 2.08 \\
$\mathrm{NE}_{\mathrm{lp}}(\mathrm{Mcal} / \mathrm{kg})^{5}$ & 1.53 & 4.63 & 1.30 & 1.27 \\
\hline
\end{tabular}

Note: ${ }^{1}$ Total digestible nutrients, $\mathrm{TDN}_{1 \mathrm{x}}(\%)=\mathrm{tdNFC}+\operatorname{tdCP}+(\operatorname{tdFA} \times 2.25)+\operatorname{tdNDF}-7$ (NRC, 2001); ${ }^{2}$ Digestible energy, $\mathrm{DE}_{1 \mathrm{x}}(\mathrm{Mcal} / \mathrm{kg})=[(\mathrm{tdNFC} / 100) \mathrm{x} 4.2]+[(\mathrm{tdNDF} / 100) \mathrm{x}$ $4.2]+[(\mathrm{tdCP} / 100) \times 5.6]+[(\mathrm{FA} / 100) \times 9.4]-0.3 ;{ }^{3} \mathrm{DE} \mathrm{P}(\mathrm{Mcal} / \mathrm{kgDM})=\mathrm{DE} 1 \mathrm{X} \times \mathrm{Discount}$ $(\mathrm{NRC}, 2001) ;{ }^{4}$ Metabolisable energy, $\mathrm{MEp}=[1.01 \mathrm{x}(\mathrm{DEp})-0.45]+[0.0046 \mathrm{x}(\mathrm{EE}-3)]$ $(\mathrm{NRC}, 2001) ;{ }^{5} \mathrm{Net}$ energy for lactation, NElp $=([0.703 \mathrm{x} \mathrm{MEp}(\mathrm{Mcal} / \mathrm{kg})]-0.19)+([(0.097$ x MEp + 0.19)/97] x [EE-3]) (NRC, 2001). 
Table 2. Fatty acid compositions of control concentrate ( $21 \% \mathrm{CP})$, fresh grass, corn silage, palm oil and linseed oil.

\begin{tabular}{lccccc}
\hline \% of total FA & $\mathbf{2 1 \% C P ~ C o n c e n t r a t e}$ & Fresh grass & Corn silage & $\begin{array}{c}\text { Palm } \\
\text { oil }\end{array}$ & $\begin{array}{c}\text { Linseed } \\
\text { oil }\end{array}$ \\
\hline C8:0 & 1.03 & ND & ND & 0.05 & 0.05 \\
C10:0 & 1.09 & ND & ND & 0.02 & ND \\
C12:0 & 15.89 & 1.42 & 1.14 & 0.19 & ND \\
C14:0 & 5.75 & 0.74 & 2.09 & 0.96 & 0.06 \\
C16:0 & 16.26 & 19.66 & 19.03 & 38.29 & 4.91 \\
C18:0 & 2.92 & 3.18 & 5.56 & 4.42 & 3.46 \\
C18:1n9c & 30.11 & 6.55 & 2.52 & 40.61 & 17.88 \\
C18:2n6c & 25.29 & 19.03 & 14.21 & 13.77 & 16.97 \\
C20:0 & ND & 0.54 & 3.00 & 0.04 & ND \\
C18:3n3 & 0.34 & 48.89 & 8.00 & 0.26 & 55.87 \\
SFA & 1 & 25.53 & 30.81 & 44.05 & 8.70 \\
MUFA & & 6.55 & 2.52 & 41.07 & 17.96 \\
PUFA & 32.93 & 67.92 & 66.67 & 14.89 & 73.34 \\
Total n6 & 30.11 & 19.03 & 58.66 & 14.46 & 17.04 \\
Total n3 & 26.97 & 48.89 & 8.00 & 0.43 & 56.20 \\
PUFA:SFA & 26.63 & 2.66 & 2.16 & 0.34 & 8.43 \\
n-6/n-3 & 0.34 & 0.39 & 7.33 & 33.69 & 0.30 \\
\hline
\end{tabular}

Note: ${ }^{1}$ SFA $=$ Sum of saturated fatty acid from C4:0 - C20: 0; ${ }^{2}$ MUFA $=$ Sum of monounsaturated fatty acid from $\mathrm{C} 14: 1-\mathrm{C} 22: 1 ;{ }^{3} \mathrm{PUFA}=$ Sum of polyunsaturated fatty acids from C18:2 - C22: 6; ${ }^{4}$ Sum of n6 fatty acids C18:2n- 6 - C22:4n- $6 ;{ }^{5}$ Sum of n3 fatty acids C18:3n-3 - C22:6n-3.

\section{Intake and live weight}

The effects of linseed lipid supplement on feed intake and live weight of dairy ruminants are slightly inconsistent; the results of intake of nutrients including of dry matter intake (DMI) (Table 3), crude protein intake (CPI), ether extract intake (EEI) and net energy for lactation from a specified feed $\left(\mathrm{NE}_{\mathrm{LPintake}}\right)$ (Mcal/day) were no interaction of main treatment effects, final live weight (FLW, $\mathrm{kg}$ ) and live weight change ( $\mathrm{LWC}, \mathrm{g} / \mathrm{d}$ ) were reduced by dietary fresh grass $(P>0.05)$. 
Table 3. Effect of Linseed Oil Supplementation on DM, CP, fat and fatty acid intakes of experimental cattle.

\begin{tabular}{|c|c|c|c|c|c|c|c|c|}
\hline \multirow[t]{2}{*}{ Item } & \multicolumn{2}{|c|}{$\overline{C S}$} & \multicolumn{2}{|c|}{ FG } & \multirow[b]{2}{*}{ SEM } & \multicolumn{3}{|c|}{ Pr $>F$} \\
\hline & $\begin{array}{c}\text { 300g/d } \\
\text { PO }\end{array}$ & $\begin{array}{c}\mathbf{3 0 0} \\
\text { g/d } \\
\text { LSO }\end{array}$ & $\begin{array}{c}\text { 300g/d } \\
\text { PO }\end{array}$ & $\begin{array}{c}\text { 300 } \\
\text { g/d } \\
\text { LSO }\end{array}$ & & Roughage & Oil & Roughage $\times$ Oil \\
\hline ILW (kg) & 402 & 397 & 374 & 378 & 2.84 & 0.195 & 0.992 & 0.790 \\
\hline FLW (kg) & 404 & 401 & 369 & 374 & 8.20 & 0.077 & 0.964 & 0.822 \\
\hline $\operatorname{LWC}(\mathrm{g} / \mathrm{d})$ & +67 & +128 & -150 & -150 & 116 & 0.300 & 0.897 & 0.897 \\
\hline \multicolumn{9}{|l|}{ DMI, kg/d } \\
\hline Concentrate & 6.1 & 6.1 & 6.1 & 6.1 & - & - & - & - \\
\hline Roughage & 9.6 & 9.8 & 5.8 & 6.1 & 0.23 & $<0.01$ & 0.560 & 0.990 \\
\hline Oil & 0.3 & 0.3 & 0.3 & 0.3 & - & - & - & - \\
\hline Total & 16.0 & 16.3 & 12.3 & 12.3 & 0.30 & $<0.01$ & 0.658 & 0.990 \\
\hline $\begin{array}{l}\text { DMI, } \\
\text { g/BW0.75 }\end{array}$ & 174.9 & 180.4 & 141.4 & 143.3 & 3.31 & $<0.01$ & 0.589 & 0.789 \\
\hline \multicolumn{9}{|l|}{$\mathrm{CPI}, \mathrm{g} / \mathrm{d}$} \\
\hline Concentrate & 1,280 & 1,280 & 1,280 & 1,280 & - & - & - & - \\
\hline Roughage & 639 & 657 & 588 & 616 & 19.90 & 0.259 & 0.575 & 0.899 \\
\hline Total & 1,920 & 1,937 & 1,869 & 1,896 & 51.05 & 0.656 & 0.826 & 0.960 \\
\hline \multicolumn{9}{|l|}{ EEI, g/d } \\
\hline Concentrate & 171 & 171 & 171 & 171 & - & - & - & - \\
\hline Roughage & 86 & 88 & 103 & 109 & 3.31 & $<0.01$ & 0.561 & 0.981 \\
\hline Oil & 300 & 300 & 300 & 300 & - & - & - & - \\
\hline Total & 558 & 560 & 518 & 520 & 7.14 & 0.195 & 0.801 & 0.930 \\
\hline \multicolumn{9}{|l|}{ NDFI, $\mathrm{kg} / \mathrm{d}$} \\
\hline Concentrate & 281.4 & 281.4 & 281.4 & 281.4 & - & - & - & - \\
\hline Roughage & 588.9 & 609.5 & 376.0 & 393.8 & 14.43 & $<0.01$ & 0.513 & 0.961 \\
\hline Total & 870.3 & 890.9 & 657.4 & 675.2 & 16.57 & $<0.01$ & 0.568 & 0.967 \\
\hline \multicolumn{9}{|l|}{$\begin{array}{l}\text { NE } \text { LPintake, } \\
\text { Mcal/d }\end{array}$} \\
\hline Concentrate & 9.4 & 9.4 & 9.4 & 9.4 & - & - & - & - \\
\hline Roughage & 10.4 & 12.8 & 7.4 & 7.8 & 0.53 & $<0.01$ & 0.223 & 0.364 \\
\hline Oil & 1.39 & 1.39 & 1.39 & 1.39 & - & - & - & - \\
\hline Total & 21.2 & 23.5 & 18.1 & 18.5 & 0.64 & $<0.01$ & 0.310 & 0.451 \\
\hline
\end{tabular}




\section{Milk production and milk composition}

The supplementing the diets of dairy cows by treatments had no effect on milk production and composition (Table 4). A higher 5\% LSO supplementation in a grass hay based diet did not affect milk production either.

Table 4. Effect of Linseed Oil Supplementation on Milk yield (MY) and milk composition of dairy cows.

\begin{tabular}{|c|c|c|c|c|c|c|c|c|}
\hline \multirow[b]{2}{*}{ Item } & \multicolumn{2}{|c|}{$\mathbf{C S}$} & \multicolumn{2}{|c|}{ FG } & \multirow[b]{2}{*}{ SEM } & \multicolumn{3}{|c|}{$\operatorname{Pr}>F^{2}$} \\
\hline & $\begin{array}{c}300 \mathrm{~g} / \mathrm{d} \\
\text { PO }\end{array}$ & $\begin{array}{c}\mathbf{3 0 0} \\
\text { g/d } \\
\text { LSO }\end{array}$ & $\begin{array}{c}300 \mathrm{~g} / \mathrm{d} \\
\text { PO }\end{array}$ & $\begin{array}{c}\mathbf{3 0 0} \\
\text { g/d } \\
\text { LSO }\end{array}$ & & Roughage & Oil & RoughagexOil \\
\hline $\mathrm{MY}, \mathrm{kg} / \mathrm{d}$ & 13.5 & 12.8 & 12.1 & 12.4 & 0.58 & 0.447 & 0.831 & 0.686 \\
\hline $\begin{array}{l}3.5 \% \mathrm{FCM} \\
(\mathrm{kg} / \mathrm{d})\end{array}$ & 14.59 & 13.41 & 12.86 & 13.28 & 0.49 & 0.361 & 0.706 & 0.430 \\
\hline Fat & & & & & & & & \\
\hline$\%$ & 4.07 & 3.88 & 3.93 & 4.01 & 0.13 & 0.987 & 0.829 & 0.604 \\
\hline $\mathrm{g} / \mathrm{d}$ & 549 & 497 & 476 & 497 & 18.05 & 0.367 & 0.649 & 0.322 \\
\hline Protein & & & & & & & & \\
\hline$\%$ & 3.05 & 2.98 & 3.02 & 3.01 & 0.05 & 0.988 & 0.707 & 0.775 \\
\hline $\mathrm{g} / \mathrm{d}$ & 412 & 381 & 365 & 373 & 13.54 & 0.323 & 0.713 & 0.586 \\
\hline Lactose & & & & & & & & \\
\hline$\%$ & 4.8 & 4.78 & 4.7 & 4.63 & 0.04 & 0.209 & 0.645 & 0.747 \\
\hline $\mathrm{g} / \mathrm{d}$ & 648 & 612 & 569 & 574 & 27.98 & 0.319 & 0.737 & 0.767 \\
\hline SNF & & & & & & & & \\
\hline$\%$ & 8.57 & 8.46 & 8.44 & 8.36 & 0.08 & 0.484 & 0.578 & 0.927 \\
\hline $\mathrm{g} / \mathrm{d}$ & 1,157 & 1,083 & 1,021 & 1,037 & 45.21 & 0.333 & 0.724 & 0.683 \\
\hline TS & & & & & & & & \\
\hline$\%$ & 12.64 & 12.39 & 12.38 & 12.35 & 0.18 & 0.688 & 0.702 & 0.754 \\
\hline $\mathrm{g} / \mathrm{d}$ & 1,706 & 1,586 & 1,498 & 1,531 & 59.24 & 0.303 & 0.707 & 0.564 \\
\hline
\end{tabular}

\section{Milk fatty acid composition}

Supplementing $300 \mathrm{~g} / \mathrm{d}$ LSO with ad libitum FG significantly increased MUFA, PUFA, n6 FA and n3 FA concentrations, but decreased milk fat SFA concentration and n-6/n-3 ratio $(P<0.01$, Table 5), whereas LSO supplementation with roughage sources significantly increased concentration of $\mathrm{C} 4: 0, \mathrm{C} 8: 0$ and decreased $\mathrm{C} 12: 0$ to $\mathrm{C} 16: 0(P<0.01)$. Therefore, there was an interaction effect of oil supplement and roughage source for milk fat (C18:3n-3 FA). Among these intermediates, $\mathrm{C} 18: 2 \mathrm{n} 6 \mathrm{t}$ and $\mathrm{C} 18: 1 \mathrm{n} 9 \mathrm{t}$ showed that the largest increase observed at $3 \%$ of dietary supplementation of LSO (Table 5). 
Table 5. Effect of Linseed Oil Supplementation on Milk fatty acid composition of dairy cows ( $\%$ of total FA).

\begin{tabular}{|c|c|c|c|c|c|c|c|c|}
\hline \multirow[b]{2}{*}{$\begin{array}{l}\% \text { of total } \\
\text { FA }\end{array}$} & \multicolumn{2}{|c|}{ CS } & \multicolumn{2}{|c|}{ FG } & \multirow[b]{2}{*}{ SEM } & \multicolumn{3}{|c|}{ Pr $>\mathbf{F}$} \\
\hline & $\begin{array}{c}\text { 300g/d } \\
\text { PO }\end{array}$ & $\begin{array}{c}\mathbf{3 0 0} \\
\text { g/d } \\
\text { LSO }\end{array}$ & $\begin{array}{c}\text { 300g/d } \\
\text { PO }\end{array}$ & $\begin{array}{c}300 \\
\text { g/d } \\
\text { LSO }\end{array}$ & & Roughage & Oil & Roughage $\times$ Oil \\
\hline $\mathrm{C} 4: 0$ & 1.58 & 2.58 & 1.74 & 2.57 & 0.053 & 0.506 & $<0.01$ & 0.450 \\
\hline C6:0 & 1.50 & 1.53 & 1.60 & 1.58 & 0.042 & 0.372 & 0.961 & 0.760 \\
\hline $\mathrm{C} 8: 0$ & 0.68 & 0.99 & 0.94 & 1.17 & 0.014 & $<0.01$ & $<0.01$ & 0.164 \\
\hline C10:0 & 1.55 & 1.71 & 1.36 & 1.36 & 0.012 & $<0.01$ & $<0.01$ & 0.003 \\
\hline C12:0 & 1.88 & 1.58 & 1.76 & 1.36 & 0.009 & $<0.01$ & $<0.01$ & 0.010 \\
\hline C14:0 & 8.08 & 7.53 & 7.62 & 6.80 & 0.010 & $<0.01$ & $<0.01$ & $<0.01$ \\
\hline $\mathrm{C} 14: 1$ & 0.75 & 0.68 & 0.67 & 0.68 & 0.005 & $<0.01$ & $<0.01$ & $<0.01$ \\
\hline C16:0 & 28.23 & 25.30 & 27.17 & 23.97 & 0.068 & $<0.01$ & $<0.01$ & 0.336 \\
\hline C16:1 & 1.49 & 1.40 & 1.55 & 1.41 & 0.010 & 0.069 & $<0.01$ & 0.214 \\
\hline C18:0 & 12.27 & 12.55 & 12.55 & 12.45 & 0.020 & 0.036 & 0.028 & $<0.01$ \\
\hline $\mathrm{C} 18: \ln 9 \mathrm{t}$ & 6.22 & 8.35 & 6.94 & 9.55 & 0.018 & $<0.01$ & $<0.01$ & $<0.01$ \\
\hline $\mathrm{C} 18: \ln 9 \mathrm{c}$ & 30.26 & 29.13 & 30.22 & 30.17 & 0.073 & $<0.01$ & $<0.01$ & $<0.01$ \\
\hline $\mathrm{C} 18: 2 \mathrm{n} 6 \mathrm{t}$ & 0.53 & 0.85 & 0.60 & 1.08 & 0.017 & $<0.01$ & $<0.01$ & 0.027 \\
\hline $\mathrm{C} 18: 2 \mathrm{n} 6 \mathrm{c}$ & 2.29 & 2.10 & 2.22 & 2.04 & 0.028 & 0.406 & $<0.01$ & 0.720 \\
\hline C20:0 & 0.22 & 0.17 & 0.20 & 0.14 & 0.003 & $<0.01$ & $<0.01$ & 0.463 \\
\hline C18:3n6 & 0.01 & 0.01 & 0.01 & 0.01 & 0.006 & 0.646 & 0.640 & 0.646 \\
\hline C20:1 & 0.06 & 0.02 & 0.04 & 0.02 & 0.002 & 0.013 & $<0.01$ & 0.013 \\
\hline C18:3n3 & 0.56 & 1.06 & 0.77 & 1.17 & 0.013 & $<0.01$ & $<0.01$ & 0.150 \\
\hline CLA c9,t11 & 1.15 & 1.39 & 1.25 & 1.71 & 0.011 & $<0.01$ & $<0.01$ & $<0.01$ \\
\hline C20:2 & 0.10 & 0.07 & 0.11 & 0.05 & 0.003 & 0.451 & $<0.01$ & 0.011 \\
\hline $\mathrm{C} 22: 0$ & 0.11 & 0.45 & 0.11 & 0.05 & 0.056 & 0.091 & 0.218 & 0.096 \\
\hline C20:3n6 & 0.02 & 0.02 & 0.02 & 0.02 & 0.002 & 0.255 & 0.817 & 0.490 \\
\hline $\mathrm{C} 22: \ln 9$ & 0.02 & 0.02 & 0.01 & 0.02 & 0.002 & 0.168 & 0.639 & 0.168 \\
\hline C20:3n 3 & 0.01 & 0.02 & 0.01 & 0.02 & 0.001 & 0.063 & $<0.01$ & 0.781 \\
\hline C20:4n6 & 0.17 & 0.15 & 0.16 & 0.12 & 0.004 & 0.014 & $<0.01$ & 0.420 \\
\hline $\mathrm{C} 22: 2$ & 0.02 & 0.02 & 0.01 & 0.01 & 0.002 & 0.239 & 1.000 & 1.000 \\
\hline $\mathrm{C} 24: 0$ & 0.03 & 0.04 & 0.04 & 0.03 & 0.005 & 0.931 & 0.931 & 0.794 \\
\hline $\mathrm{C} 22: 6 \mathrm{n} 3$ & 0.04 & 0.09 & 0.12 & 0.13 & 0.008 & $<0.01$ & 0.056 & 0.246 \\
\hline $\mathrm{C} 20: 5 \mathrm{n} 3$ & 0.04 & 0.04 & 0.05 & 0.04 & 0.003 & 0.233 & 0.628 & 0.469 \\
\hline SFA $^{1}$ & 56.14 & 54.42 & 55.08 & 51.48 & 0.081 & $<0.01$ & $<0.01$ & $<0.01$ \\
\hline MUFA $^{2}$ & 38.80 & 39.59 & 39.44 & 41.85 & 0.078 & $<0.01$ & $<0.01$ & $<0.01$ \\
\hline PUFA $^{3}$ & 5.06 & 5.99 & 5.48 & 6.67 & 0.038 & $<0.01$ & $<0.01$ & 0.098 \\
\hline$n-6^{4}$ & 4.31 & 4.70 & 4.42 & 5.23 & 0.038 & $<0.01$ & $<0.01$ & 0.011 \\
\hline$n-3^{5}$ & 0.66 & 1.22 & 0.97 & 1.41 & 0.017 & $<0.01$ & $<0.01$ & 0.085 \\
\hline$n-6 / n-3$ & 6.66 & 3.87 & 4.59 & 3.79 & 0.114 & $<0.01$ & $<0.01$ & $<0.01$ \\
\hline
\end{tabular}

Note: ${ }^{1}$ SFA $=$ Sum of saturated fatty acid from C4:0 - C20:0; ${ }^{2}$ MUFA $=$ Sum of monounsaturated fatty acid from C14:1 $-\mathrm{C} 22: 1 ;{ }^{3}$ PUFA $=$ Sum of polyunsaturated fatty acids from C18:2 - C22:6; ${ }^{4}$ Sum of n6 fatty acids C18:2n-6 - C22:4n-6; ${ }^{5}$ Sum of n3 fatty acids C18:3n-3 - C22:6n-3; SEM is standard error of mean. 


\section{DISCUSSION}

No interaction of main treatment effects occurred for intake of nutrients (Table 3). However, the ANOVA of main effects showed that cows fed diets based on corn silage consumed more total dry matter (DM) than fresh grass $(P<0.01)$ which had greater $\mathrm{CF}, \mathrm{NDF}$ and ADF compared to corn silage. In the case of fresh forage, high water content is often mentioned as a factor regulating DM intake (Forbes, 1995). Phillips et al. (1991) showed that the high water content of forages could limit intake in cattle and sheep. Tafaj et al. (2007) reported that DMI linearly decreased with increasing dietary NDF. Forage NDF is a major factor affecting feed intake and rumen fill in high-producing cows. However, DMI in the current experiment (4.92 g/100 g of concentrate, DM) were not reduced by oil supplementation. There was no interaction between oil and roughage sources on ether extract intake (EEI, g/d) and net energy for lactation intake (NELP intake). However, cows fed diets based on corn silage consumed more EE and NELP than those cows on fresh grass $(P<0.01)$.

Milk production and composition were unaffected by treatments (Table 4). Loor et al. (2005) did not observe any effect of less than 5\% LSO on milk production when added either to forage based or concentrate based diets of dairy cows. A higher 5\% LSO supplementation in a grass hay based diet did not affect milk production either. In the present experiment, adding oil to dairy cow diets did also not affect milk composition. Similarly, inclusion of plant lipids in the concentrate had no effect on milk yield or milk composition in cow fed red clover silage, possibly because the intake of DM and ME was similar across treatments (Filleau et al., 2011). Milk fat content was unaffected by treatments (Table 4). Chilliard et al. (2009) and Shingfield et al. (2010) reported no effect of dietary oil supplementations on milk fat content. In the present experiment, LSO did not affect milk protein (Table 4). The effect of oils on milk protein content has also been variable. Bu et al. (2007) reported no effect of LSO addition on milk protein. In contrast, Loor et al. (2005) and Flowers et al. (2008) observed an increase in milk protein content of grazing cows supplemented with LSO. Variability between studies in milk composition response to oil supplementation could be explained not only by the amount of oil added to the diet but also by the composition of the basal diet. No significant relationships were found between the amount of fat added (ranged from 200 to $1,000 \mathrm{~g} /$ day) and the response in milk or FCM production, or between the milk production response and the level of milk production of the cows (ranged from 11 to $31 \mathrm{~kg} /$ day) (Schroeder et al., 2004)

The MUFA, PUFA, n6 FA and n3 FA concentrations increased throughout from $300 \mathrm{~g} / \mathrm{d}$ LSO supplementation with ad libitum FG, whereas a significantly decrease in SFA concentration and n-6/n-3 ratio were detected in milk fat $(P<0.01)$. The FA composition of milk fat depends on various dietary characteristics including roughage to concentrate ratio (Sterk et al., 2011), FA 
intake, FA metabolism in the mammary gland (Chilliard et al., 2007). LSO supplementation with roughage sources significantly increased concentration of C4:0, C8:0 and decreased C12:0 to C16:0 $(P<0.01)$. Furthermore, $300 \mathrm{~g} / \mathrm{d}$ LSO with ad libitum FG decreased $\mathrm{C} 14: 0$ to $\mathrm{C} 16: 0$ in milk fat $(P<0.01$; Table 5). These effects are consistent with the reduction in de novo FA synthesis due to feeding unsaturated oils, which occurs because of greater uptake and secretion of dietary or ruminal derived FA (Benchaar et al., 2012).

The increased concentration of C18:0 in milk fat can be expected due to extensive metabolism of long chain PUFA in the rumen which leads to an increase in the amount of C18:0 for absorption (Jensen, 2002). The decreased in milk SFA content with LSO supplementation was similar between the CS and FG diets $(P<0.01$; Table 5$)$. The faster rate of oil release into the rumen from LSO could result in the higher production of trans FA in the rumen and, thus an inhibitory effect on de novo mammary lipogenesis (Chilliard et al., 2007) . Furthermore, a meta-analysis citing a range of studies in which linseed and other oil supplements decreased concentrations of long chain UFA (Glasser et al., 2008).

Feeding LSO increased C18: 1n9t, C18: 1n9c and CLA (C9, T11) $(P<0.01$; Table 5) in milk fat. This can be explained by the result from the ruminal $\mathrm{BH}$ of C18:2 and C18:3 (Shingfield et al., 2010). In particular, C18:1 could be derived from the reduction of $\mathrm{C} 18: 2$ and $\mathrm{C} 18: 3 \mathrm{n} 3$ and during ruminal metabolism, which both increased when the diet was supplemented with LSO (Benchaar et al., 2012). In the present study, the roughage sources, FG and CS, which led to an increase in C18: 1 in milk fat could, therefore, be explained by the higher supply of dietary C18:2 (Table 5) or by the overall ruminal UFA load, as suggested by Lock (2010). Duodenal flow and secretion of C18:1 in milk fatwas shown to be highly dependent on the composition of the basal diet. Feeding LSO in a diet rich in starch and based on CS as the sole forage increased milk fat content of C18: 1 (Chilliard et al., 2007). In the contrast, supplemental LSO decreased C18: 1when the diet was based on grass hay rich in fiber (Roy et al., 2006).

Milk fat content of CLA was increased with LSO supplementation (Table 5). It has been established that a great proportion of this CLA isomer found in the milk is produced endogenously in the mammary gland using C18:1 produced in the rumen as a substrate (Griinari et al., 2000). Nevertheless, for each type of forage, the specific FAs were correlated with milk fat content. Loor et al. (2005) showed that $\mathrm{C} 18: 2$ was enhanced in the duodenal digesta in response to natural grassland hay based diets containing LSO as a source of C18:3n3. There was a significant effect of oil supplement and roughage source $(P<0.01)$ interaction on C18:3n-3 FA in milk fat. The decrease in transfer efficiency observed with increasing supply of LSO could be explained by 1) an increased efficiency in biohydrogenation with higher supply of free LSO in the diet, 2) a lower intestinal digestibility with an increasing amount of C18: $3 n-3$ escaping ruminal 
fermentation as dietary LSO supply increased, or 3) a lower efficiency of mammary uptake as the arterial concentration of C18:3n-3 increased (Benchaar et al., 2012). In this regard, Loor et al. (2005) observed an increase in intestinal digestibility of C18:3n-3 with dietary supplement of LSO, which does not support a limitation in absorption capacity. At the level of the mammary gland, Enjalbert et al. (1998) reported that extraction of arterial FA, either nonesterified or in the form of triglycerides, increased with arterial concentration following duodenal infusion of long chain FA. Finally, Khas-Erdene et al. (2010) observed a quite stable efficiency of transfer to milk of duodenal infused C18:3n-3 over a wide range of FA supply. The decrease in apparent recovery of dietary $\mathrm{C} 18: 3 \mathrm{n} 3$ can be explained by the efficiency BH process, which has been shown by Loor et al. (2005) to be greater when free LSO was added in the diet.

In this case, the extent of ruminal $\mathrm{BH}$ has been assessed by calculating the proportion of dietary PUFA disappearing during their passage in the rumen (not found in the small intestine). However, this calculation does not provide any information about the efficiency of the overall series of reactions (e.g., the final production of C18:0). According to Harfoot (1981), the BH pathway of C18:3n3 involves the production of $\mathrm{C} 18: 3 \mathrm{n} 3, \mathrm{C} 18: 2 \mathrm{n} 6 \mathrm{t}$ and $\mathrm{C} 18: 1 \mathrm{n} 9 \mathrm{t}$, which can all be absorbed and incorporated in to milk fat. Among these intermediates, C18:2n6t and C18: $1 \mathrm{n} 9 \mathrm{t}$ showed a response to the level of LSO supplementation, with the largest increase observed at 3\% of dietary supplementation (Table 5). Therefore, it speculates that dietary $\mathrm{C} 18: 3 \mathrm{n} 3$ rapidly undergoes $\mathrm{BH}$ by being reduction of double bonds at carbons 6 and 9 to yield C18: 2n6t and C18: 1n9t, which accumulate in the rumen as the efficiency of the first step in the pathway increases. The average concentrations of $\mathrm{C} 18: 3 \mathrm{n} 3$ and C18:2n6 in milk fat of 300 $\mathrm{g} / \mathrm{d}$ LSO with ad libitum FG cows were 1.17 and $2.04 \%$ of total FA (Table 5). The $\mathrm{n}-6 / \mathrm{n}-3$ ratio of $3.79(P<0.01)$ falls within the recommended range, from $1: 1$ to $4: 1$, that is considered to be important for human homeostasis and normal development (Simopoulos, 2008).

For cows, main sources of C18:3n 3 and C18:2n6 were from LSO, grass and corn silage, respectively (Chilliard et al., 2001). C18:3n3 and C18:2n6 that escape rumen $\mathrm{BH}$ will probably, as in other mammals, be beta-oxidized (Cunnane et al., 2003), stored in body tissues, or incorporated in milk fat. Desaturation of C20:4n3 causes the formation of $\mathrm{C} 20: 5 \mathrm{n} 3$, which is subsequently elongated to form $\mathrm{C} 22: 5 \mathrm{n} 3$. In humans, the main products formed out of $\mathrm{C} 18: 3 \mathrm{n} 3$ are $\mathrm{C} 20: 5 \mathrm{n} 3$ and $\mathrm{C} 22: 5 \mathrm{n} 3$; the latter may have beneficial effects (Kaur et al., 2011) and may serve as a substrate for metabolic retro conversion to C20:5n3 (Russo, 2009). However, the absorption levels of $\mathrm{C} 22: 5 \mathrm{n} 3$ and the conversion rate to $\mathrm{C} 20: 5 \mathrm{n} 3$ have never been reported. In the generally accepted n-3 FA partway, C22:5n3 is further converted into C24:5n-3, C24:6n-3, and finally C22:6n3. The conversion of $\mathrm{C} 22: 5 \mathrm{n} 3$ is the rate limiting step for the conversion of C18:3n-3 to C22:6n-3 (Arterburn et al., 2006). Unfortunately, the intermediates C24: 5n- 3 and C22:6n-3 could not be determined in the present study, which makes it impossible 
to determine the actual rate-limiting step. Concentrations of C22:6n-3 were lower than $0.20 \%$ of total FA of fat in all treatments, which is in agreement with the low conversion rates from $\mathrm{C} 18: 3 \mathrm{n}-3(<0.1 \%)$ that are frequently reported in the literature (Williams and Burdge, 2006). In the present analyses, we used the average FA content of milk. Milk FA composition is not constant and feeding trials have shown that concentrations of very long chain PUFA may increase significantly due to variation in the diets of dairy cows. For example, the C22: $6 n-3$ concentration may be increased from 0.04 to $0.13 \%$ of total FA upon supplementation of the dairy cow diet with linseed oil (Zachut et al., 2010).

\section{CONCLUSION}

Supplementing $300 \mathrm{~g} / \mathrm{d}$ oil (PO and LSO) to roughage sources (CS and FG) did not negatively affect DMI, milk yield, milk production and milk composition. Milk fatty acid proportions of n-3FA increased, whereas total SFA decreased with the addition of LSO in the diet. As a result of changes in these FAs, the ratio of n- 6 to n-3 was lowered in dairy cow supplemented with LSOFG as compared with other treatments. It can be concluded that $300 \mathrm{~g} / \mathrm{d} \mathrm{LSO}$ can be safely supplemented to forage-based diets of dairy cows to enrich milk with potential health-beneficial FA without causing any detrimental effect on animal performance.

\section{ACKNOWLEDGEMENTS}

The authors are grateful thanks to Institute of Research and Development, School of Animal Technology and Innovation, Institute of Agricultural Technology, Suranaree University of Technology, Thailand.

\section{REFERENCES}

Ambroise, M. 2001. Apports Nutritionnels Conseilles (ANC) for the French population. Reproduction Nutrition Development. 41: 119-128. https://doi. org/10.1051/rnd:2001100

AOAC. 1990. Official Methods of Analysis. 2. $15^{\text {th }}$ ed. Arlington, VA: AOAC. Arterburn, L. M., Hall, E. B., and Oken, H. 2006. Distribution, interconversion, and dose response of $\mathrm{n}-3$ fatty acids in humans. The American Journal of Clinical Nutrition. 83: 1467-1476. https://doi.org/10.1093/ajen/ 83.6.146 $7 \mathrm{~S}$ 
Benchaar, C., Romero-Pérez, G.A., Chouinard, P.Y., Hassanat, F., Eugene, M., Petit, H.V., and Côrte, C. 2012. Supplementation of increasing amounts of linseed oil to dairy cows fed total mixed rations: Effects on digestion, ruminal fermentation characteristics, protozoal populations, and milk fatty acid composition. Journal of Dairy Science. 95: 4578-4590. https://doi.org/ $10.3168 /$ jds.2012-5455

Bu, D.P., Wang, J. Q., Dhiman, T.R., and Liu, S. J. 2007. Effectiveness of oils rich in linoleic and linolenic acids to enhance conjugated linoleic acid in milk from dairy cows. Journal of Dairy Science. 90: 998-1007. https://doi.org/10.3168/jds.S0022-0302(07)71585-0

Chilliard, Y., Ferlay, A., and Doreau M. 2001. Effect of different types of forages, animal fat or marine oils in cow's diet on milk fat secretion and composition, especially conjugated linoleic acid (CLA) and polyunsaturated fatty acids. Livestock Production Science. 70: 31- 48. https://doi.org/10.1016/S0301-6226(01)00196-8

Chilliard, Y., Glasser, F., Ferlay, A., Bernard, L., Rouel, J., and Doreau M., 2007. Diet, rumen biohydrogenation and nutritional quality of cow and goat milk fat. European Journal of Lipid Science and Technology. 109: 828-855. https://doi.org/10.1002/ejlt.200700080

Chilliard, Y., Martin, C., Rouel, J., and Doreau, M. 2009. Milk fatty acids in dairy cows fed whole crude linseed, extruded linseed, or linseed oil, and their relationship with methane output. Journal of Dairy Science. 92: 5199-5211. https://doi.org/10.3168/jds.2009-2375

Cunnane, S.C., Ryan, M.A., Nadeau, C.R., Bazinet, R.P., Musa-Veloso, K., and McCloy, U. 2003. Why is carbon from some polyunsaturates extensively recycled into lipid synthesis? Lipids. 38: 477-484. https://doi.org/10.1007/ s11745-003-1087-8

Dewhurst, R. J., Scollan, N.D., Lee, M.R.F., Ougham, H. J., and Humphreys, M. O. 2003. Forage breeding and management to increase the beneficial fatty acid content of ruminant products. Proceedings of the Nutrition Society. 62: 329-336. https://doi.org/10.1079/PNS2003241

Enjalbert, F., Nicot, M.C., Bayourthe, C., and Moncoulon, R. 1998. Duodenal infusions of palmitic, stearic or oleic acids differently affect mammary gland metabolism of fatty acids in lactating dairy cows. Journal of Nutrition. 128: 1525-1532. https://doi.org/10.1093/jn/128.9.1525

Filleau, H.B.A., Kokkonen, T., Lampi, A.M., Toivonen, V., Shingfield, K.J., and Vanhatalo, A. 2011. Effect of plant oils and camelina expeller on milk fatty acid composition in lactating cows fed diets based on red clover silage. Journal of Dairy Science. 94: 4413-30. https://doi.org/10.3168/jds.20103885 
Flowers, G., Ibrahim, A.S., and Ghazaleh, A.A. 2008. Milk fatty acid composition of grazing dairy cows when supplemented with linseed oil. Journal of Dairy Science. 91: 722-730. https://doi.org/10.3168/ jds.20070410

Folch, J., Lees, M., and Sloane-Stanley, G.H. 1957. A simple method for the isolation and purification of total lipids from animal tissues. Journal of Biological Chemistry. 226: 497-509.

Forbes, J. M. 1995. Ruminant gastrointestinal tract. In: Forbes, J. M., editor. Voluntary Food Intake and Diet Selection in Farm Animals. Wallingford: CAB International. p. 59-80.

Glasser, F., Ferlay, A., and Chilliard, Y. 2008. Oilseed lipid supplements and fatty acid composition of cow milk: a meta-analysis. Journal of Dairy Science. 91: 4687-4703. https://doi.org/10.3168/jds.2008-0987

Griinari, J.M., Corl, B.A., Lacy, S.H., Chouinard, P. Y., Nurmela, K. V. V., and Bauman, D.E. 2000. Conjugated linoleic acid is systhesized endogenously in lactating dairy cows by delta-9-desaturase. Journal of Nutrition. 130: 2285-2291. https://doi.org/10.1093/jn/130.9.2285

Harfoot, C.G. 1981. Lipid metabolism in the rumen. In: W.W. Christie, editor. Lipid Metabolism in Ruminant Animals. Oxford: Pergamon Press Ltd. p. 21-55.

Harvatine, K.J., Boisclair, Y.R., and Bauman, D.E. 2009. Recent advances in the regulation of milk fat synthesis. Animal. 3: 40-54. https://doi.org/10.1017/ S1751731108003133

Jensen, R. G. 2002. The composition of bovine milk lipids: January 1995 to December 2000. Journal of Dairy Science. 85: 295-350. https://doi.org/ 10.3168/jds.S0022-0302(02)74079-4

Kaur, G., Cameron-Smith, D., Garg, M., and Sinclair, A.J. 2011. Docosapentaenoic acid (22:5n-3): A review of its biological effects. Progress in Lipid Research. 50: 28-34. https://doi.org/10.1016/j.plipres.2010.07.004

Khas-Erdene, Q., Wang, J. Q., Bu, D. P., Wang, L., Drackley, J. K., Liu, Q. S., Yang, G., Wei, H.Y., and Zhou, L.Y. 2010. Responses to increasing amounts of free $\alpha$-linolenic acid infused into the duodenum of lactating dairy cows. Journal of Dairy Science. 93: 1677-1684. https:// doi. org/10.3168/jds. 20092681

Lock, A.L. 2010. Update on dietary and management effects on milk fat. In: Proceedings of Tri-State Dairy Nutrition Conference; Fort Wayne, IN, Columbus: The Ohio State University. p. 15-26.

Loor, J.J., Ferlay, A., Ollier, A., Doreau, M., and Chilliard, Y. 2005. Relationship among trans and conjugated fatty acids and bovine milk fat yield due to dietary concentrate and linseed oil. Journal of Dairy Science. 88: 726-740. https://doi.org/10.3168/jds.S0022-0302(05)72736-3 
Metcalfe, L.D., Schimitz, A.A., and Pelka, J.R. 1966. Rapid preparation of fatty acid ester from lipid for chromatographic analysis. Analytical Chemistry. 38: 514-515. https://doi.org/10.1021/ac60235a044

Ostrowska, E., Dunshea, F.R., Muralitharan, M., and Cross, R.F. 2000. Comparison of silver- ion high- performance liquid chromatographic quantification of free and methylated conjugated linoleic acids. Lipids. 35: 1147-1153. https://doi.org/10.1007/s11745-000-0630-y

Phillips, C.J.C., Margerison, J.K., Azazi, S., Chamberlain, A.G., and Omed, H. 1991. The effect of adding surface water to herbage on its digestion by ruminants. Grass and Forage Science. 46: 333-338. https://doi.org/10.1111/j.13 65-2494.1991.tb02238.x

Romeu-Nadal, M., Morera-Pons, S., Castellote, A.I., and Lopez-Sabater, M. C. 2004. Comparison of two methods for the extraction of fat from human milk. Analytica Chimica Acta. 513: 457-461. https://doi. org/10.1016/j. aca. 2004.02.038

Roy, A., Ferlay, A., Shingfield K. J., and Chilliard, Y. 2006. Examination of the persistency of milk fatty acid composition responses to plant oils in cows fed different basal diets, with particular emphasis on trans-C18: 1 fatty acids and isomers of conjugated linoleic acid. Journal of Animal Science. 82: 479-492. https://doi.org/ 10.1079/ASC200658

Russo, G. L. 2009. Dietary n- 6 and n- 3 polyunsaturated fatty acids: From biochemistry to clinical implications in cardiovascular prevention. Biochemical Pharmacology. 77: 937-946. https://doi.org/10.1016/j.bcp. 2008.10.020

SAS (Statistical Analysis System). 2001. SAS user' guide: Statistics. NC: SAS Institute.

Schroeder, G.F., Gagliostrob, G.A., Bargoc, F., Delahoyc, J.E., and Muller, L.D. 2004. Effects of fat supplementation on milk production and composition by dairy cows on pasture: a review. Livestock Production Science. 86: 1-18. https://doi.org/10.1016/S0301-6226(03)00118-0

Shingfield, K. J., Bernard, L., Leroux, C., and Chilliard, Y. 2010. Role of trans fatty acids in the nutritional regulation of mammary lipogenesis in ruminants. Animal. 4: 1140-1166. https://doi.org/10.1017/S175173111000 0510

Shingfield, K.J., Ahvenjarvi, S., Toivonen, V., Vanhatalo, A., Huhtanen, P., and Griinari, J. M. 2008. Effect of incremental level of sunflower-seed oil in the diet on ruminal lipid metabolism in lactating cows. British Journal of Nutrition. 99: 971-983. https://doi.org/10.1017/S0007114507853323

Simopoulos, A.P. 2008. The importance of the omega-6/omega-3 fatty acid ratio in cardiovascular disease and other chronic diseases. Experimental Biology and Medicine. 233: 674-688. https://doi.org/10.3181/ 0711-MR-311 
Steel, R.G.D., and Torries, J.H. 1980. Principles and procedures of statistics. A Biometrical Approach. $2^{\text {nd }}$ ed. New York: M.C. Graw-Hill Book Co. p. 1-688.

Steijns, J.M. 2008. Dairy products and health: Focus on their constituents or on thematrix? International Dairy Journal. 18: 425-435. https://doi.org/10.10 16/j.idairyj.2007.11.008

Sterk, A., Vlaeminck, B., Van Vuuren, A. M., Hendriks, W.H., and Dijkstra, J. 2011. Effects of feeding different linseed sources on omasal fatty acid flows and fatty acid profiles of plasma and milk fat in lactating dairy cows. Journal of Dairy Science. 95: 3149-3165. https://doi.org/10.3168/jds.20114474

Tafaj, M., Zebeli, Q., Baes, C.H., Steingass, H., and Drochner, W. 2007. A metaanalysis examining effects of particle size of total mixed rations on intake, rumen digestion and milk production in high-yielding dairy cows in early lactation: Review. Animal Feed Science and Technology. 138: 137-161. https://doi.org/10.1016/j.anifeedsci.2007.06.020

Van Soest, P.J., Robertson, J.B., and Lewis, B.A. 1991. Methods for dietary fiber, neutral detergent fiber and non starch polysaccharides in relation to animal production. Journal of Dairy Science. 74: 3583-3597. https://doi.org/10.31 68/jds.S0022-0302(91)78551-2

Williams, C.M., and Burdge, G. 2006. Long-chain n-3 PUFA: Plant v. marine sources. Proceedings of the Nutrition Society. 65: 42-50. https://doi.org/ 10.1079/PNS2005473

Zachut, M., Arieli, A., Lehrer, H., Livshitz, L., Yakoby, S., and Moallem, U. 2010. Effects of increased supplementation of n- 3 fatty acids to transition dairy cows on performance and fatty acid profile in plasma, adipose tissue, and milk fat. Journal of Dairy Science. 93: 5877-5889. https://doi.org/10. $3168 /$ jds.2010-3427 